cent of units and $33 \cdot 7$ per cent of personnel were engaged exclusively or mainly in fundamental research, compared with $62 \cdot 1$ per cent and $54 \cdot 1$ per cent, respectively, for applied research.

Nearly 10 per cent of the scientific units employed no persons with university qualifications and nearly 90 per cent of the units employed not more than 10, while about a quarter had no technicians or trained auxiliaries. Some 60 per cent employed no one with technical diplomas and nearly half the remainder employed only one such person. In the educational sector, 24 units employed some 15 per cent of the university graduates, mainly in the faculties of science and medicine, while in the public sector 13 per cent were employed in 3 per cent of the units in this sector, especially at the Centre for the Study of Nuclear Energy. Excluding the educational sector in the exact sciences, about half the units spent less than 1 million francs on research in 1961, and half these not more than 700,000 francs. In the public sector, including research associations, half the units spent not more than 3 to 4 million francs, while ten private enterprises, responsible for 60 per cent of the expenditure on such activities by private enterprise, spent more than 50 million franes and 5 of those 100 million franes.

\title{
REGIONAL ADMINISTRATION IN FRANCE
}

\begin{abstract}
A
PAMPHLET, The French Administrative Reform, issued by the Press and Information Service of the French Embassy, describes the structures of the Departments, of the Paris region, and of the other Regions as modernized by the decrees of March 14, 1964 (Pp. 30. London: Ambassade de France, Service de Presse et d'Information, 1964). The reforms, which will be implemented over a period extending to at least 1965, are based on the results of experiments conducted during two years in five test departments and in the pilot regions of Upper Normandy and Burgundy. The basic principle consists in making the Prefect once more solely responsible for the State service; the sole representative of the Government in the Department, he is the sole co-ordinator of public activities, with the exception of the military services, judicial services, assessment and collection of taxes, payment of public expenses, valuation of national property, factory inspection and supervision of the application of the social loans in agriculture. To ensure that the Prefect is fully informed of all important aspects of life in his Department, a central correspondence service will provide photographic copies of incoming letters, while copies of outgoing letters will also be submitted. Delegation of power is provided for certain highly technical services but delegation of signature allows more freedom and flexibility to heads of services.

A similar principle has been applied to the regions but only to external services concerned with economic matters, public investment and equipment, those which manage Government stocks or participate in programmes
\end{abstract}

involving national public funds. Such State services in the regions will be placed directly under the Prefect of the Region and cease to be directly under the Paris ministries. The Prefect will accordingly now have a role of initiation and decision in the economic field and a simple function of co-ordination in the administrative field. He will be assisted by an enlarged inter-departmental administrative conference and by a new com. mission on regional economic development. The new commission will be consulted when the Government prepares future development plans, after the draft has been submitted to Parliament and again after the final planning project has been discussed by Parliament and the operative sections relating to each region have been defined.

This regional reform does not apply to the Paris region, the administrative districts of which are being subdivided to give smaller units while a single assembly will replace the General Council and the Municipal Council, retaining on the whole the powers of the present Municipal Council and assuming those possessed by the General Council of the Seine. The suburbs are to be divided into Departments of normal status, while the pilot prefectures will permit construction of national administrative cities in each chief town. Provision is also made for a system of administrative and economic co-ordination, including a regional assembly or council, the composition of which is not yet fixed. Additional financial resources will be provided and it is anticipated that the new organization should be functioning smoothly by 1968 .

\section{THE BUILDING RESEARCH STATION}

\begin{abstract}
A its headquarters in Bucknalls Lane, Garston, Watford, Herts., the Building Research Station (Department of Scientific and Industrial Research) had its 'Open Days, 1964' during September 22-25, when members of the public, including Press representatives, were accorded an unrivalled opportunity of seeing something of the inside workings of this long-established and important organization. Displays and hourly full-scale demonstrations illustrating some of the more important activities of the Station and many items of present-day research were made available to the visitors. In the department concerned with building operations and economics, the theme is research into the efficiency and economy of building operations, development of new techniques, examination of methods of management and organization, and factors influencing costs. Mechanical engineering deals with research applied to production and handling of building components on site and in the factory, and investigations in the engineering services requisite to completed buildings. Environmental physics is concerned both
\end{abstract}

with factors controlling conditions in buildings and with the subjective reactions of the occupants to these conditions. The section devoted to user requirements and design deals with building design and occupants' requirements in relation to housing and to some special building types. Research in the materials department ranges from the constitution and properties of building materials to investigation of their behaviour in use, including laboratory-scale tests to pilot plant trials. Structural engineering is concerned fundamentally with loadings, with the behaviour both of components and of full-scale and model structures, and with the engineering properties of building materials.

The soil mechanics department was the first to be set up in Britain. It has done pioneer work on the engineering properties of soils and their relationship to the structural behaviour of foundations, tunnels, retaining walls and earth dams. A section devoted to mathematics provides a service for the rest of the Station, and present-day work, reflecting projects in three other departments, includes the 